\title{
The fragmentation of a discipline: how diversity elevates and undermines ir's normative potential
}

Nicolas Alexander Beckmann*

\section{ABSTRACT}

International Relations (IR) has transformed from a relatively state-centric discipline that was primarily concerned about international security and the behavior of great powers into a highly diverse intellectual playing field. The present article assesses the implications of this transformation in relation to IR's normative potential, defined in terms of knowledge production and critical thinking. Although the field's growing diversity helps addressing the multiple challenges and crises the world is currently facing, it is also evident that the specialized knowledge and jargon that is needed to engage in a specific subfield prevents IR scholars from understanding one another. This development not only undermines the liveliness of the field, but also obstructs our capacity to interact with political actors and engage with the public. Furthermore, inwardlooking scholarly communities curtail critical thinking. Although there is no panacea that can reverse this trend, the article claims that cultivating networks of dialogue may assuage its worst effects by facilitating mutual learning and improving our communicative skills.

Key words: Diversity, fragmentation, knowledge, critical thinking, communication

* Ph.D. in International Relations, Florida International University, 2019. Magíster en estudios internacionales, Universidad Torcuato Di Tella, 2013. B.A. in Political Management, Hochschule Bremen, 2010. Profesor y coordinador del Área de Relaciones Internacionales, miembro del Grupo de Investigación en Estudios Políticos, Facultad de Ciencias Políticas, Escuela de Derecho y Ciencias Políticas, Universidad Pontificia Bolivariana, Antioquia (Colombia). [nicolas.beckmann@upb.edu.co]; [https://orcid.org/0000-0001-6969-4213].

Recibido: 30 de noviembre de 2019 / Modificado: 9 de marzo de 2020 / Aceptado: 15 de marzo de 2020

Para citar este artículo:

Beckmann, N. A. (2020). The fragmentation of a discipline: how diversity elevates and undermines ir's normative potential. OASIS, 32, pp. 11-28.

DOI: https://doi.org/10.18601/16577558.n32.03 


\section{La fragmentación de una disciplina: cómo diversidad eleva y socava el potencial normativo de las relaciones internacionales}

\section{RESUMEN}

Las relaciones internacionales (RR.II.) se han ido transformando de una disciplina relativamente Estado-céntrica, que principalmente se preocupa por la seguridad internacional y el comportamiento de las grandes potencias, en un campo de juego intelectual mucho más diverso. El presente artículo evalúa las implicaciones de esta transformación en relación con el potencial normativo de las RR.II., el cual es definido en términos de producción de conocimiento y pensamiento crítico. Aunque la creciente diversidad ayuda a abordar los múltiples desafíos y crisis a los que se enfrenta la humanidad, también es evidente que el conocimiento y la jerga especializados, que son necesarios para participar en un subcampo particular, impiden que los académicos de las RR.II. se entiendan entre ellos. Este desarrollo no solo socava la vitalidad de nuestro campo de estudio, sino que también obstruye nuestra capacidad de interactuar con actores políticos y relacionarnos con el público. Además, comunidades académicas que solo miran hacia adentro minimizan el pensamiento crítico. Aunque no existe una panacea para revertir esta tendencia, el artículo afirma que el cultivo de redes de diálogo puede mitigar sus peores efectos al facilitar el aprendizaje mutuo y mejorar nuestras habilidades comunicativas.
Palabras clave: diversidad, fragmentación, conocimiento, pensamiento crítico, comunicación

\section{INTRODUCTION}

Concerns about the state of International Relations (IR) have become a common theme in the discipline. However, most authors disagree about what exactly is wrong and how to move forward. This is no surprise given that IR has undergone a major transformation from a state-centered discipline, concerned primarily about international security and the behavior of great powers, into a much more diverse intellectual playing field. Nowadays, IR is home to a multitude of subfields, which distinguish themselves in terms of issue areas, regional expertise, and diverse ontological, epistemological and methodological commitments. The present article assesses the implications of this transformation in relation to IR's normative potential, defined in terms of knowledge production and critical thinking.

Although IR's diversification is generally positive, the article also identifies some downsides. On the positive side, the relatively recent diversity poses fewer restrictions about what can be studied under the umbrella of IR. This not only allows researchers to engage with topics they are truly passionate about, but it also enables them to address more adequately the multiple challenges and crises the world is currently facing. However, the growing diversity is driving a process of fragmentation that has several problematic effects. As outlined below, scholars who advance their careers by becoming members in one of IR's numerous 
inward-looking camps that hold different beliefs, use different lexica, and hardly talk to one another, find it increasingly difficult to comprehend what researchers in other areas are doing. This not only weakens engagement and mutual learning within the discipline, but also hampers effective communication with political actors and the public.

Based on this assessment, the present article claims that the difficulties of effectively communicating research findings beyond our specialized subfields seriously weakens IR's normative potential. Put differently, what is the value of our discipline if it produces knowledge that cannot be understood and interpreted by decision-makers and large segments of the public? To construct the claim that diversity both elevates and undermines the field's normative potential, the article proceeds in three steps. First, it reflects and critically assesses two central aspects of IR's normativity: knowledge production and critical thinking. The objective is to obtain some clarity about the discipline's possible contributions to our societies as well as the field's limitations. The second part of the article briefly substantiates the assertion that IR has transformed from a relatively state-centric discipline, concerned primarily about international security, into a much more diverse field of study. It claims that nowadays researchers can analyze any type of social interactions and challenges that have in- ternational or transnational dimensions, based on competing ontological and epistemological assumptions, while using a wide array of research methods. The third part evaluates the effects of these changes in relation to the discipline's normative potential. While diversity is necessary to produce knowledge that may help address and attenuate some of the many problems the world is facing, the insularity of many subfields hinders the diffusion of this knowledge as well as critical thinking.

To mitigate this development, the last part of this article makes a case for the cultivation of networks of dialogue across the different camps. As argued below, the exercise of dialogue not only facilitates mutual understanding but also has the potential of enhancing our communicative skills. Although it is unrealistic to assume that such networks will reverse the fragmentation of the field as a whole, they can contribute to moderate its worst effects.

\section{IR'S NORMATIVE POSSIBILITIES AND LIMITATIONS}

While there is much debate about what IR can and should seek to achieve, the field is deeply entrenched by normative objectives. ${ }^{1}$ As stated by one of the discipline's most prolific and cited authors:

\footnotetext{
1 Even some of the most pessimistic accounts of world politics seek to avoid the worst possible outcomes (Morgenthau, 1948), or argue that political thinking without elements of utopianism is sterile or even dangerous (Carr, 1946; and Morgenthau, 1962). Furthermore, as highlighted by Cox (1981) and, more recently, Dunne, Hansen \& Wight (2013), even theories that seek to merely describe the world carry instructions on how actors should behave.
} 
We do not study international relations for aesthetic reasons, since world politics is not beautiful. If we sought scientific rigor we would have pursued careers in experimental disciplines. Instead we are motivated by normative questions, often asked urgently in the wake of disasters, from the Sicilian Expedition (416 BCE) chronicled by Thucydides to the AngloAmerican invasion of Iraq (2003 CE). Recurring failures lead us to try to understand the conditions under which states and other actors can achieve their collective purposes rather than engage in destructive, and often self-destructive behavior (Keohane, 2008, p. 708).

However, the assertion that IR is an essentially normative enterprise that should contribute to peace and social welfare is not without controversy. On the last page of his opus magnum, The Anarchical Society, Hedley Bull (2002) expresses deep skepticism about "the search for conclusions that can be presented as 'solutions' or 'practical advice," which he views as "a corrupting element in the study of world politics" fueled by demands and possibilities for profit (p. 308). Instead, he portrays world politics as "an intellectual activity and not a practical one" (ibid.). Following this line of thought, he dismisses commenting on current international affairs as a legitimate but extracurricular activity "for which no academic credit is due" (Bull, 2000, p. 262).

While Bull's skepticism constitutes a valid warning about the limitations of producing policy-relevant knowledge (see below), viewing IR merely as an intellectual activity is not very appealing either. As argued by Morgenthau (1962), "By engaging in activities which can have no relevance for the political problems of the day, such as theorizing about theories, one can maintain one's reputation as a scholar without running any political risks. This kind of international theory, then, is consummated in theorizing for theorizing's sake, an innocuous intellectual pastime engaged in by academicians for the benefit of other academicians and without effect on political reality as it is unaffected by it" (p. 77). Although Morgenthau's argument that "theorizing for theorizing's sake" has little practical value misses the point, he is right in claiming that IR researchers should not abstain themselves from intervening in the debates on contemporary issues. All societies need experts that help them to make sense of what is going on in the multiple issue and geographic areas of our planet. Why should IR scholars leave this field entirely to journalists and political commentators? Although it is not fair to expect all researchers of global politics to become public intellectuals, we certainly miss opportunities if we withdraw ourselves completely from public debates. Our role to society becomes particularly important when our findings, or even our scholarly intuitions, contradict dominant discourses or ideas that gain popularity in public debates. Yet, given the uncertainty of IR's knowledge, it is important to discuss in some detail the potential, as well as the limitations, of our contributions to contemporary debates. Put differently, what should be the role of our field in democratic societies? The following paragraphs flesh out two key elements of what IR can and should aspire to accomplish. It is argued that generating (im- 
perfect and contestable) knowledge that may help societies to solve collective problems ${ }^{2}$ and make more informed decisions is at the core of IR's normativity. Moreover, precisely because the knowledge IR generates is contestable on various grounds, the discipline is able to facilitate the apprehension of another skill that is crucial to the functioning of democratic societies: critical thinking. In this sense, "theorizing about theories" can be a highly practical and useful activity even if it has no direct relation to current events. But before elaborating this point in greater detail, the following analysis examines the limitations and importance of knowledge creation in IR.

As stated above, the claim that IR should produce practical or socially-relevant knowledge is not without problems. The constant interaction of multiple analytical components, advances in technology, and changes in the human psyche generate high levels of ambiguity and uncertainty in almost any political scenario. Furthermore, biases related to our senses, languages, values and worldviews constantly interfere with our analysis. Other limitations include the dearth, or poor quality, of existing data; a lack of access to the circles in which high-level policy decisions are taking place; the fluidity and vagueness of the categories we use for our analysis, such as norms or power; and ultimately the incapacity to look into the mindset of decision-makers, which leaves us guessing in doubt about their intentions (Jackson, 2016; Hollis \& Smith, 1990; Mearsheimer \& Walt, 2013; Morgenthau, 1948; and Vázquez, 1995; among others). As emphasized by Jackson (2016), even the existence of an objective reality, which many scholars take for granted, is a philosophical wager or personal belief that cannot be proven or disproven. All of this obliges us to accept that our academic products are inevitably contestable and ambiguous, which makes their relevance to policy problematic. As stated by Oren (2016), "To the extent that scientists do not agree on the precise properties of their objects of study, empirical results are likely to be ambiguous and open to multiple interpretations even if the methods being employed are highly technical" (p. 574). Moreover, "Because empirical objects are typically referred to in everyday terms (e.g., democracy, corruption), the use of specialized techniques hardly guarantees that research results would be accepted without controversy (Ibid., p. 575).

Despite these shortcomings it is also clear that we cannot engage in meaningful political conversation or analysis if we do not base our claims on something that goes beyond our own perception. Otherwise, how could we reject recent statements by the president of Brazil, arguing that the fires in the Amazon rain forest were lit by NGOs in an effort to obtain publicity? Or, how would we counter a claim

2 For the author, the notion of solving problems is not opposed at all to critical theory, which seeks to overcome social, economic and political orders. Critical theories also attempt to solve problems though on a different scale than so-called problem-solving theories (for a similar argument see: Brown, 2013). 
stating that Colombia's GDP growth in 2018 was actually $10 \%$ rather than $2.7 \%$. In other words, to make meaningful claims in diverse issue areas, we depend on descriptive data that has been generated by professional standards. Mearsheimer \& Walt (2013) rightly criticize the questionable quality of the data used in IR. Does this, however, mean that we should not attempt to generate reliable data, and refrain from interpreting available, data? The answer is a clear no. Generating and interpreting data about inter and transnational phenomena constitutes a necessary condition for informed discussions and decision-making and is indispensable for the evaluation of public policies, political systems, economic models and world orders. When this data is flawed, it needs to be questioned and, to the extent that this is possible, improved. ${ }^{3}$ However, neglecting data generation and improvement altogether, opens the door to debates and decision-making based entirely on emotions and perceptions, which is far more problematic.

Of course, the task of knowledge production goes beyond the mere generation of reliable data and accurate descriptions of inter and transnational phenomena. What IR scientists, broadly defined, ought to aspire to is to explain or understand important aspects of world politics. ${ }^{4}$ As outlined above, the tasks of explaining and understanding political phenomena face numerous limitations, which require a degree of modesty regarding our choice of research methods as well as our conclusions. As stated by Bull (2002), "It is better to recognize that we are in the darkness than to pretend that we can see the light" (p. 308). Does this mean, however, that we should abandon the enterprise of explaining and understanding international phenomena? Once again, the answer is a clear no. If we want to assuage any type of problem or issue affecting our societies, we need to have an idea about its causes and underlying conditions. While the answers about the causes and consequences of social phenomena will never be entirely accurate, they are indispensable for potentially more informed decisions. Of course, it is questionable to what extent government officials and decision-makers want or have the luxury of taking into consideration the analyses of social scientists, especially if their findings contradict political agendas. However, what matters for our discipline is to make this knowledge available and accessible so that a more informed debate and decision-making process can (not must) take place.

Knowledge production in IR is intimately tied to the development of theories, which can inform or may follow from empirical analysis. Broadly defined, theories can be understood

3 To provide an example, the edited volume Sex, Drugs, and Body Counts by Andreas \& Greenhill (2010) demonstrates the misrepresentation and politicization of quantitative data related to criminal activities. Although their analysis does not solve the problem of data generation on illicit activities, it reinforces scrutiny and skepticism in the evaluation of claims about organized crime.

4 On the difference between explanation and understanding in the social sciences see Hollis \& Smith (1990). 
as systemic reflections, intellectual devices, or mental maps that make the world more intelligible or better understood (see Dunne et al., 2013). ${ }^{5}$ While different modes of theorizing fulfill multiple functions for the analysis of international phenomena (see Guzzini, 2013), theories that explain international phenomena or reflect on how the world functions have considerable practical value for decision-making. For Morgenthau (1962), international theory may not only "bring order and meaning into a mess of unconnected material" (p. 72) but also help making more educated guesses about the future: "What a theory of international relations can state is the likely consequences of choosing one alternative as over against another and the conditions under which one alternative is more likely to occur and be successful than the other. Theory can also say that under certain conditions one alternative is to be preferred over another" (p. 70). Mearsheimer \& Walt (2013) highlight that theories are particularly useful in the absence of hard facts or reliable information, as it is the case in the messy domain of international politics: "In the absence of reliable information, we have little choice but to rely on theory to guide our analysis" (p. 436). In this sense, theory development not only facilitates and accompanies the task of knowledge production but also imparts an element of rationality in decision-making processes.

Apart from providing (imperfect and contestable) knowledge, IR is able to foster and facilitate the apprehension of another vital activity and skill: critical thinking. The term can be broadly defined as "reasonable or reflective thinking that is focused on deciding what to believe or do" (Ennis, 1991, p. 8). This exercise involves comparing and evaluating different knowledge claims against one another on the basis of logical consistency, the available evidence, historical analysis and philosophical reasoning. The importance of critical thinking for our societies cannot be underestimated in the current era of uncertainty and misinformation. On the one hand, governments simultaneously have to deal with a multitude of global challenges, changes brought about by technology, and the rising tensions between the world's most powerful states. Decisionmakers with strong skills in critical thinking and reflexivity are better equipped to interpret the risks and possibilities of uncertain political contexts (Guzzini, 2013). On the other hand, as the recent revelations about big tech companies have shown, citizens across the world are not only being bombarded with (mis)information but are also manipulated through targeted advertisements, based on estimates of their

\footnotetext{
5 For Viotti and Kauppi (2003) theory developments goes beyond the mere description of observed phenomena and engaging in causal explanations and predictions. For the author of this article, this separation is problematic. Even the description of social phenomena depends on some notions of theory, and so do the exercises of explanation and prediction. Furthermore, most theories contain descriptive, explanatory, and predictive elements. While theories are an indispensible ingredient of knowledge production, theories themselves can be considered as knowledge claims about how the world or parts of the world function.
}

OASIS, ISSN: 1657-7558, E-ISSN: 2346-2132, N³2, Julio-Diciembre de 2020, pp. 11-28 
personality and preferences. These challenges arguably make the capacity to evaluate information and political arguments even more important than in previous eras. Although standards of assessing information will always have a subjective dimension, experienced critical thinkers are better equipped to differentiate a valid knowledge claim from an explicit lie, detect flaws in the validity or soundness of arguments, and spot rhetorical tricks that are aimed to disguise such flaws.

Of course, such skills can be acquired in multiple settings and the discipline of IR is far from the only possible training ground. However, IR has certain features that comprise particularly strong potential to foster critical thinking. First and foremost, the field is shaped by ontological, epistemological, and methodological uncertainties that cannot be resolved by pure reason. The dearth and questionable quality of the data used in IR further complicates knowledge production (see above). These uncertainties imply that all research is imperfect and contestable on various grounds. Although this poses strong limitations on the possibility of accumulating knowledge, it provides an excellent environment to practice critical thinking. From early on, students of IR are schooled to reflect critically on ontological claims and empirical findings. This exercise strengthens our competence to compare and evaluate political discourses, ideas, and arguments as well as to analyze political challenges.

Second, despite the recent rush towards hypothesis testing in American IR ${ }^{6}$, the discipline is strongly tied to the development of theory, broadly defined. ${ }^{7}$ While the competition between different grand theories has been rightly criticized as a resemblance of "theological debates between academic religions" (Lake, 2011), the clash of opposing ideas and mental maps about the nature of world politics, or certain aspects of it, strengthens critical thinking in several ways. On the one hand, theory development not only depends on imagination and creativity but also requires abstract and logical thinking about the infinite factors that can possibly influence a phenomenon. Furthermore, abstraction and reflection are needed to define key concepts and assess their relationships. On the other hand, as theories are simplifying devices with limited explanatory power, students of IR constantly evaluate their applicability or illuminate important issues they neglect. In fact, numerous contributions that have expanded the boundaries of the field stem from critiques of dominant theories and modes of thinking in the discipline

6 On the growing popularity of hypothesis testing in U.S. IR, see: Mearsheimer \& Walt (2013); and Oren (2016). For a competing argument see: Kristensen (2018).

7 On the one hand, many IR syllabi and textbooks are designed along the lines of different of different grand theories or schools of thought. Hence, a majority of IR students views the field through the lens of competing theories about the nature of international politics. On the other hand, while the evolution of grand theories has arguably slowed down, many IR scholars develop, examine or test so-called middle-range theories, which seek to explain or understand specific phenomena of world politics (Jackson \& Nexon, 2013). 
(Ashley, 1984; Bull, 2002; Carr, 1946; Cox 1981; Lapid \& Kratochwil, 1995; Ling, 2014; Sylvester, 1994; Tickner \& Blaney, 2012; among others). Ultimately, while prominent IR theories arguably reflect a Western outlook on the world, interestingly they also provide a counterpoise to ethnocentrism and dominant foreign policy discourses. This is particularly true for the realist school whose associated authors have argued that dominant powers tend to disguise their interests in Universalist moral discourses (Carr, 1946; and Morgenthau, 1948); protested against the U.S. invasion of Iraq; criticized the excesses of U.S. power and the expansion of NATO into Eastern Europe (Mearsheimer, 2011 and 2014); and defended the right of Iran to acquire nuclear weapons (Waltz, 2012). ${ }^{8}$ In this sense, theories provide IR students with powerful tools to question dominant discourses and foreign policy decisions (for a similar argument see: Morgenthau, 1962).

Third, while Rosenberg (2016) and others lament that IR has failed to generate any big ideas that have impacted other branches of the social sciences, IR's openness and capacity to incorporate concepts, theories, and knowledge produced in other fields, including the natural sciences, has created a huge playing ground for the discussion, contestation, and combination of infinite ideas and multiple traditions of doing research. To my mind, it is precisely this multidisciplinary aspect that makes IR stand out in relation to other fields in which dominant paradigms are not scrutinized and questioned to the same extent.

After having outlined knowledge creation and critical thinking as two crucial aspects of IR's normativity, the following sections analyze how IR's recent diversification both elevates and undermines the field's normative potential. The paragraphs below start with a brief assessment of how IR has diversified over the past decades.

\section{THE DIVERSIFICATION OF INTERNATIONAL RELATIONS}

Claiming that IR has become more diverse and that this diversification represents a true transformation is not without problems. After all, the field is still characterized by a clear dominance of the English language, positivist research methods, gate-keeping about what can be said in the field's leading publications, and evidence of a U.S. hegemony. Data from the 2014 Teaching, Research and International Policy (TRIP) World Faculty Survey revealed that scholars employed at U.S. universities constitute about a third of all IR professors, and that almost 41 percent of the survey's respondents received their highest degree from a U.S. institution. Furthermore, according to a majority of IR scholars the most influential journals are largely U.S.-American (Maliniak, Peterson, Powers \& Tierney, 2018). One could argue that U.S. centrism would not be so problematic, if its academy was open to ideas,

8 Brown (2013) makes a similar case for liberal authors under the Bush administration. 
theories, and epistemologies from abroad. However, Maliniak et al. (2018) found that the U.S. is highly "insular," meaning that it is relatively closed to approaches and ideas from other parts of the world. What further complicates the picture is that even though most scholars in the U.S. report using qualitative methods, since 1980 articles applying quantitative methods far outnumber other ones in IR's top journals (Maliniak, Oakes, Peterson \& Tierney, 2011). This bias favoring Englishlanguage publications based on a positivist epistemology and employing quantitative methods certainly prevents researchers that do not or cannot commit to these standards from making it to the upper ranks of the field.

Despite these shortcomings, if we look at trends in IR beyond the U.S., evidence suggests an increasing diversification of the field. In thirteen of the 32 countries that formed part of the TRIP survey, the number of IR topics studied exceeded ten, and only in three countries this number was lower than five. Also, in eleven countries scholars studied at least four different regions (Maliniak et al. 2018). Furthermore, although the field's top 12 journals (according to impact factor scales) shared a strong commitment to positivist research, the next four journals on these scales have a reputation of publishing non-positivist research (ibid.).

Another important trend in IR is the incorporation of critical, feminist, postcolonial, and poststructuralist approaches into the core of field. Although it is true that these approaches do not enjoy the same standing as the traditional ones, they are well represented at major conventions held by the ISA and the World International Studies Committee (wISC). Moreover, they form part of popular undergraduate textbooks on global politics (Baylis, Smith \& Owens, 2017; and Dunne, Kurki \& Smith, 2013). The rising popularity of Acharyas and Buzan's (2019) Global IR, which envisions a "truly inclusive and universal discipline," has given further legitimacy to new and diverse ways of doing research (p. 298). Despite the authors' defense of the discipline's conventional theories and methods, their call for greater inclusiveness and diversity may facilitate the fieldwide recognition of critical, feminist, postcolonial, and poststructuralist scholarship. If this tendency continues, these approaches will have higher possibilities of impacting the thinking of future researchers and practitioners.

The most far-reaching trend, however, is a reconfiguration of traditional concerns about international security, global power alignments, and the behavior of great powers to multiple areas of study. This has facilitated a separation of the field into myriad issueareas, including the classical ones such as International Security Studies (Iss), Foreign Policy Analysis (FPA), International Law, and International Political Economy (IPE), as well as newer ones like the global environment, area studies, migration, public health, the study of transnational advocacy and social movements, and human rights, which often operate under the umbrella term Global Issues. These diverse issue areas or subfields are often further divided by different theoretical, epistemological and 
methodological commitments. ${ }^{9}$ While it is true that not all subfields, issue areas, and approaches to research enjoy the same standing, this article agrees with Oren (2016) in that "there is no clear hierarchy of research priorities and little centralized theoretical integration" (p. 575).

This growing diversification inevitably raises the question of what unites IR as a discipline or field of study. In other words, is there some kind of common core that unifies scholars doing IR? While such a core arguably existed in the early stages of the discipline, it is questionable whether it does today. Hence, instead of a common feature that unites IR, the field is best characterized by Wittgenstein's concept of "family resemblance," i.e., a set of overlapping similarities in which no feature is common to all elements. As highlighted by Silvester (2013), IR has become a field of difference, "fragmented and diversified as new cadres, topics, and interests came over, through, and around the walls of IR, ignoring the old ways and insisting on identifying and studying the international and its relations as they saw fit" (p. 610). Other authors have raised similar arguments, characterizing IR as a fragmented adhocracy (Oren, 2016), cacophony (Jackson \& Nexon, 2013), administrative holding company (Hermann, 1998) and "a constellation of hermetically sealed and self-referential sub-communities" (Kornprobst, 2009, p.
87). The following section analyzes how this transformation affects IR's normative potential.

\section{IMPLICATIONS FOR IR'S NORMATIVITY}

The above-outlined broadening of the discipline has many advantages. The disappearance of restrictions about what can be studied under the umbrella of IR not only allows the field's scholars to follow their inclinations and curiosities but also helps to address more adequately the multiple challenges and crises the world is currently facing. As illustrated above, although the knowledge IR is able to produce is always imperfect and contestable, this knowledge is nevertheless crucial for more informed debates and decision-making processes about issues as diverse as the worsening condition of the global ecosystem, privacy in the digital sphere, new diseases and public health, the instability of financial markets, food security, terrorism, and the various challenges related to organized crime. Although IR is far from being the only field that can contribute to knowledge production in these areas, it is perhaps the only one that can incorporate and freely combine concepts, tools, theories, and data from multiple disciplines to carry out insightful analyses about issues that have inter or transnational dimensions.

Furthermore, as a consequence of IR's diversity, power, knowledge, and reputational

$9 \quad$ For example, according to Buzan and Hansen (2009) Iss is divided into no less than nine different approaches and subfields: Peace Research, Feminist Security Studies, Conventional Constructivism, Critical Constructivism, Post-colonialism, Human Security, Critical Security Studies, the Copenhagen School, and Poststructuralism. 
structures have become flatter and more decentralized. This provides more agency to non-core voices and researchers as it gets easier for them to connect with less hierarchical and smaller groups of scholars interested in the same topics. As highlighted by Wæver (1998), "most subfields are relatively tolerant, welcome new members, and are not terribly competitive” (p. 718). Similarly, Oren (2016) affirms that IR's "reputational hierarchy has become more fluid and ambiguous" (p. 594). Sylvester (2013) strikes a similar chord arguing that "there is a group, a camp, for every major interest. You do not have to suffer a turn away from field publications: there is a journal on every IR street corner. That side of academic IR is covered better than at any time in the field's history" (p. 620).

While this development does not resolve all of the difficulties that scholars from the global South are facing (see Tickner, 2013), it is nevertheless a significant improvement for researchers who have not received training in the U.S. or do not want to commit to a neo-positivist epistemology and methods. In any case, the relative opening of the field is not only an issue of justice, enabling non-core voices to be heard in a field that seeks to study global issues, but also a highly practical matter. An informed debate about the globe's most pressing concerns cannot take place without knowledge and perspectives from diverse locations. Hence, the field's opening carries the potential for the IR community as a whole to become a better contributor to global debates.

However, it is important to recognize that IR's growing diversity also led to a serious disconnect between scholars engaged in these multiple camps. As Sylvester (2013) argued: "the smoke from proliferating IR campfires makes it increasingly difficult to see even friendly neighboring camps, let alone those pitched purposely at a remove. I see the inability of today's IR to communicate across diversity as problematic when it comes to conceptualizing and understanding the many dimensions of our world" (p. 610). There are several reasons that help explain this trend: Obtaining the specialized knowledge that is necessary to engage with a subfield is timeconsuming and makes it harder to keep track and interact with other researchers who are engaged in their own subfields. Furthermore, Oren (2016) indicates that "to publish results and harvest reputations, researchers must convince specialists in their subfield that their research meets the subfield's norms of technical competence and that their findings are useful to them" (p. 574). These dynamics encourage the use of strong jargon, thereby discouraging others from more engagement. While the highly specialized knowledge and jargon utilized in the different subfields helps explain the absence of interesting intra-disciplinary conversations, Sylvester (2013) also takes on the field's campfire spirit: "Since many IR camps have their own journals, it becomes relatively easier to concentrate on preferred orientations and to assume that other journals do likewise. Ironic as it might be, the professional IR camp scene today can seem conservative even as it is liberating" (p. 615). Because of these factors, pervasive difficulties to understand what substantive knowledge is being produced in IR's different camps are characteristic of the field's fragmented nature. The implications 
of this fragmentation, however, go far beyond our discipline. If we, as a field of study, have a hard time communicating what we are doing to one another, how can we expect the public or decision-makers to pay attention to what we have to say?

While effective communication and knowledge diffusion constitute a substantial challenge, the field's fragmentation also produces some downsides for IR's capacity to foster critical thinking. Although in theory diversity should facilitate big clashes of ideas, concepts, and theories, most debates tend to take shape about relatively narrow issues within the different camps (Sylvester, 2013). Kornprobst (2009) underlines that "All too often adherents to different perspectives make no to little effort to listen to what the other side has to say, or, even more common, refuse to talk to one another altogether" (p. 87). For the author, this development tends to eclipse heterogeneity, which he considers essential for a lively scholarly community; entrenches cherished assumptions; stifles innovation; streamlines research questions; and reduces the scrutiny of research findings (ibid.). Similarly, Hermann (1998) asserts that "the lack of communication and interaction often breeds distrust and the formation of stereotypes concerning the research of those that do not share our outlook" (p. 606). As emphasized above, these tendencies not only diminish intra-disciplinary discussions, but also undermine the field's possibility to engage with the public and affect decision-making processes.

The challenges outlined above are neither new nor has there been a shortage of calls or suggestions to help overcome them. While
Keohane's (1988 and 1989) panacea was for all camps to adopt a positivist epistemology and methods, Lake (2011) pushed for a common IR lexicon to be centered around the concepts of "actors pursuing interests while engaged in interactions with other actors within institutions" (p. 473). Other suggestions include a constant updating of IR's dictionary (Guzzini, 2013), focusing on theory development based on causal mechanisms (Bennett, 2013), and greater meta-theoretical reflection (Reus-Smit, 2013). From the menu of available options, the present article clearly sides with those authors who have called for a greater intra-disciplinary dialogue (Hermann, 1998; Kornprobst, 2009; Lapid, 1989; and Sylvester, 2013).

Seeking to push a highly diverse and simultaneously conservative discipline to adopt a particular epistemology, the use of a specific set of methods, a common vocabulary or certain modes of theorizing, is not only bound to fail but will inevitably generate discriminations and exclusions. Moreover, as argued above, diversity is an invaluable asset to make sense of global politics and its multiplicity of highly complex challenges. Without having to sacrifice diversity and conceding epistemological and ontological positions, dialogue, however, enhances the potential of diluting stereotypes, promoting understanding, finding a common language and improving our communicative capacities (Hermann, 1998; and Kornprobst, 2009). Although it is commonly upheld that the field's positions are irreconcilable, Kornprobst (2009) made a convincing case that even positivist and post-positivist approaches to IR share similarities in their resemblance of aspects of epistemological positions of ancient 
Greece (Aristotelian Rhetoric and Philosophical Sophistic). Hence, IR is best understood as a field of overlapping horizons rather than incommensurable paradigms, which should open up possibilities for dialogue (ibid.).

\section{FOSTERING NETWORKS OF DIALOGUE}

Making a case for more dialogue does not turn a blind eye to the difficulties involved in overcoming the in-group-out-group dynamics that currently shape the field. As highlighted by Hermann (1998): "stereotypes are much more easily maintained than changed" (p. 612). Moreover, the rules for a constructive dialogue outlined by Kornprobst (2009)—an open mind, commitment to inclusivity, engagement with each other's arguments, focus on an issue domain, and embracing the open-ended nature of dialogue-appear far too ambitious to be followed by large groups of researchers. It is also important to stress that scholars who have not perfected English are at a clear disadvantage to engage in a dialogue on equal footing in a largely English-speaking field.

Despite these insuperable difficulties, undertaking steps that facilitate dialogue can render important benefits. Dialogue can start at the smallest possible scale, for example by having a friendly colleague, who is not part of the same camp, read one's article and asking him or her for feedback. Such exchanges have multiple benefits. At a minimum, our colleagues will be able to point out which parts of the article are hard to comprehend for nonexperts and what aspects will need revision if we want to make our findings available to audiences beyond our subfield. At best, he or she, will be able to provide a fresh perspective and give critical input so that we can improve our argument or target it to different audiences. Such exchanges may also enable the encounter of points of contact with other subfields or literatures that we have been unaware of, thereby helping to expand our horizons. Interactions of this type can be easily replicated on larger scales, for example in the form of research colloquia, workshops, or conferences that welcome diversity. Furthermore, depending on the topic and article, journals may introduce some flexibility to the review process by inviting non-expert reviewers that have a reputation for providing constructive feedback.

In her role as president of the ISA, Hermann (1998) suggested going even further by outlining an ambitious mechanism to foster understanding and dilute stereotypes. Specifically, she proposed conferences where participants would be asked to present the research papers of another scholar who is working in an area that overlaps but is not identical with one's own specialization. The other scholar would be at the meeting but present someone else's work, instead of his or her own. For Hermann (1998), incentivizing these mechanics will lead to deeper forms of engagement than within the standard proceedings of academic conferences: "You are more likely to work harder to understand the nuances of the research and try to be true to what is written than when you were asked to be a discussant on a panel and certainly than when you are a member of an audience hearing the material for the first time" (p. 613).

While such initiatives require some commitment, leadership and willingness to experi- 
ment, they do not depend on top-level incentives. It is up to those researchers interested in learning from, and engaging with, distinct audiences to create and foster networks with like-minded colleagues. There are good reasons to assume that the engagement in such networks will help to mitigate some of the problems outlined above, even though the field as a whole is likely to remain fragmented.

\section{CONCLUSION}

The present article has sought to assess how recent changes in the discipline have affected IR's normative potential. The crux of the argument is that IR has transformed from a security-heavy discipline, concerned primarily about the interactions of powerful states, into a much more diverse area of study that is able to contribute to the understanding of diverse issues affecting our globe. Yet, diversity also has its downsides. Multiple camps within IR have lost touch with each other and pay more attention to their own distinctive analysis than engaging with other audiences. The growing disconnect is not only problematic for the health of our field but hinders the diffusion of our knowledge, which should inform public debates and decision-making processes. Furthermore, insularity reduces the IR's potential to foster critical thinking, as the field falls short of interesting debates between competing perspectives.

The reasons for the current state are diverse, complex, and hard to overcome. Nevertheless, IR scholars envisioning a more interactive and communicative field do not need to feel resigned. As long as there are other researchers interested in exchanges of ideas across different camps, we can set up and foster networks of dialogue as a counterbalance to IR's insular nature. These networks can range in terms of size, focus, formality and ambition. The hope is that the continued practice of dialogue will not only enrich our understanding of world politics by approaching it from different angles but also enhance our communicative skills. The importance of such dialogues points to the very essence of IR's normativity, which is to provide knowledge that may help to make the world a better place. However, unless our community learns to communicate with greater comfort what we are learning about the world to diverse audiences, we will remain a fragmented field of small inward-looking camps with very little social and political significance.

\section{REFERENCES}

Acharya, A. \& Buzan, B. (2019). The making of Global International Relations: Origins and evolution of IR at its centenary. Cambridge: Cambridge University Press.

Andreas, P. \& Greenhill, K. M. (2010). Sex, drugs, and body counts: The politics of numbers in global crime and conflict. Ithaca and London: Cornell University Press.

Ashley, R. K. (1984). The poverty of neorealism. International Organization, 38(2), 225-286.

Baylis, J.; Smith, S. \& Owens, P. (Eds.). (2017). The globalization of world politics: An introduction to International Relations ( $7^{\text {th }}$ ed.). Oxford: Oxford University Press.

Bull, H. (2000). International Relations as an academic pursuit (1972). In K. Alderson \& A. Hurrell 
(Eds.), Hedley Bull on international society (246264). London: Palgrave Macmillan.

Bull, H. (2002). The anarchical society: A study of order in world politics ( $3^{\text {rd }}$ ed.). New York: Columbia University Press.

Buzan, B. \& Hansen, L. (2009). The evolution of International Security Studies. Cambridge: Cambridge University Press.

Brown, C. (2013). The poverty of grand theory. European Journal of International Relations, 19(3), 483-497.

Carr, E. H. (1946). The twenty year's crisis 1919-1939: An introduction to the study of world politics ( $2^{\text {nd }} \mathrm{ed}$.). London: MacMillan \& Co. Ltd.

Cox, R. (1981). Social forces, states and world order: Beyond International Relations theory. Millenium Journal of International Affairs, 10(2), 126-155.

Dunne, T.; Hansen, L. \& Wight, C. (2013). The end of International Relations theory? European Journal of International Relations, 19(3), 405-425.

Dunne, T.; Kurki, M. \& Smith, S. (Eds.). (2014). International Relations theories: Discipline and diversity ( $3^{\text {rd }}$ ed.). Oxford: Oxford University Press.

Ennis, R. (1991). Critical Thinking: A Streamlined Conception. Teaching Philosophy, 14(1), 5-24.

Guzzini, S. (2013). The ends of International Relations theory: Stages of reflexivity and modes of theorizing. European Journal of International Relations, 19(3), 521-541.

Hermann, M. G. (1998). One field, many perspectives: Building the foundations for dialogue. International Studies Quarterly, 42(4), 605-624.

Hollis, M. \& Smith, S. (1990). Explaining and understanding International Relations. Oxford: Clarendon Paperbacks.

Jackson, P. T. (2016). The conduct of inquiry in International Relations ( $2^{\text {nd }}$ ed.). New York: Routledge.

Jackson, P. T. \& Nexon, D. (2013). International theory in a post-paradigmatic era: From substantive wa- gers to scientific ontologies. European Journal of International Relations, 19(3), 543-565.

Keohane, R. O. (1988). International institutions: Two approaches. International Studies Quarterly, 32(4), 379-396.

Keohane, R. O. (1989). International Relations theory: Contributions of a feminist standpoint. Millenium - Journal of International Studies, 18(2), 245-253.

Keohane, R. O. (2008). Big questions in the study of world politics. In C. Reus-Smit \& D. Snidal (Eds.), The Oxford handbook of International Relations (708-715). Oxford: Oxford University Press.

Kornprobst, M. (2009). International Relations as rhetorical discipline: Toward (re)-newing horizons. International Studies Review, 11(1), 87-108.

Kristensen, P. M. (2018). International Relations at the end: A sociological autopsy. International Studies Quarterly, 62, 245-259.

Lake, D. (2011). Why "isms" are evil: Theory, epistemology, and academic sects as impediments to understanding and progress. International Studies Quarterly, 55(2), 465-480.

Lapid, Y. (1989). The third debate: On the prospects of international theory in a post-positivist era. International Studies Quarterly, 33(3), 235-254.

Lapid, Y. \& Kratochwil, F. (Eds.). (1995). The return of culture and identity in IR theory. Boulder: Lynne Rienner Publishers.

Ling, L. H. M. (2014). The Dao of World Politics. Toward a post-Westphalian, wordlist International Relations. New York: Routledge.

Maliniak, D.; Oakes, A.; Peterson, S. \& Tierney, M. J. (2011). International Relations in the us academy. International Studies Quarterly, 55(2), 437-464.

Maliniak, D.; Peterson, S.; Powers, R. \& Tierney M. J. (2018). Is International Relations a global disci- 
pline? Hegemony, insularity, and diversity in the field. Security Studies, 27(3), 448-484.

Mearsheimer, J. J. (2011). Imperial by design. The $\mathrm{Na}$ tional Interest, 111, 16-34.

Mearsheimer, J. J. (2014). Why the Ukraine crisis is the West's fault. The liberal delusions that provoked Putin. Foreign Affairs, 93(5), 1-12.

Mearsheimer, J. J. \& Walt, S. M. (2013). Leaving theory behind: Why simple hypothesis testing is bad for International Relations. European Journal of International Relations, 19(3), 427-457.

Morgenthau, H. J. (1948). Politics among nations: The struggle for power and peace. New York: Alfred A. Knopf.

Morgenthau, H. J. (1962). The intellectual and political functions of a theory of International Relations. In H. J. Morgenthau, Politics in the $20^{\text {th }}$ century. Vol. 1: The decline of democratic politics (62-78). Chicago: The University of Chicago Press.

Oren, I. (2016). A sociological analysis of the decline of American IR theory. International Studies Review, $18(4), 571-596$.

Reus-Smit, C. (2013). Beyond metatheory? European Journal of International Relations, 19(3), 589-608.

Rosenberg, J. (2016). International Relations in the prison of political science. International Relations, $30(2), 127-153$.
Sylvester, C. (1994). Feminist theory and International Relations in a post-modern era. Cambridge: Cambridge University Press.

Sylvester, C. (2013). Experiencing the end and afterlife of International Relations/theory. European Journal of International Relations, 19(3), 609-626.

Tickner, A. B. \& Blaney, D. L. (Eds.). (2012). Thinking International Relations differently. London and New York: Routledge.

Tickner, A. B. (2013). Core, periphery, and (neo)imperialist International Relations. European Journal of International Relations, 19(3), 627-646.

Vasquez, J. A. (1995). The post-positivist debate: Reconstructing scientific enquiry and international relations theory after enlightenment's fall. In K. Booth \& S. M. Smith, International relations theory today (217-240). Cambridge: Polity Press.

Viotti, P. R. \& Kauppi, M. V. (1987). International Relations theory: Realism, pluralism, globalism and beyond. New York: Macmillan.

Wæver, O. (1998). The sociology of a not so international discipline: American and European developments in International Relations. International Organization, 52(4), 687-727.

Waltz, K. N. (2012). Why Iran should get the bomb. Nuclear balancing would mean stability. Foreign Affairs, 91(4), 2-5. 